\title{
Preliminary Study on COD Removal on the Treatment of Palm Oil Mill Effluent (POME) Using Birnessite- Type Manganese Oxide via a Solvent-Free Method
}

\author{
Amir Awaluddin ${ }^{1 *}$ Okrida Sonia ${ }^{1}$ Muhdarina ${ }^{1}$ Amilia Linggawati ${ }^{1}$ Siti Saidah \\ Siregar ${ }^{1}$
}

\author{
${ }^{1}$ Department of Chemistry, Universitas Riau, Kampus BinaWidya, Km 12.5 Simpang Baru, Pekanbaru, Riau 28293 \\ Indonesia \\ *Corresponding author. Email: amirawaluddin01@gmail.com
}

\begin{abstract}
Palm oil mill effluent (POME) has an adverse effect on the environment due to its high toxicity, low pH, and high chemical and biological oxygen demand. The degradation using Fenton processes is considered as an attractive and sustainable way for the treatment of POME. In this study, as-synthesized birnessite-type manganese oxide was used as the Fenton catalyst for the treatment of POME. This oxide is a typical manganese oxide with an octahedral layered structured and was synthesized from the reduction of $\mathrm{MnO}_{4}^{-}$using simple sugar (glucose) as a reducing agent by a solvent-free method. The characterization of the oxide was carried out using X-Ray Diffraction (XRD), Scanning Electron Microscopy-Energy Dispersive X-ray Spectroscopy (SEM-EDX), and Surface Area Analyzer (SAA). The characterization results indicated the birnessite-type manganese oxide with a well-crystalline structure, irregular shapes of morphology, and surface area of $4.180 \mathrm{~m}^{2} / \mathrm{g}$. The degradation studies revealed that $\mathrm{H}_{2} \mathrm{O}_{2}$ concentration plays a key role in the COD removal of the POME. The maximum reduction in COD removal was $62 \%$ in 45 minutes of reaction with the catalyst concentration of $400 \mathrm{mg} / \mathrm{L}$ and $10 \mathrm{ml}$ of $\mathrm{H}_{2} \mathrm{O}_{2}$.
\end{abstract}

Keywords: POME, Fenton, birnessite, manganese oxide.

\section{INTRODUCTION}

$\mathrm{MnO}_{2}$ has a different crystal structure, depending on how the basic structure $\left(\left[\mathrm{MnO}_{6}\right]\right.$ octahedral $)$ is connected, whether by sharing edges and or corners. There are various crystallographic forms of $\mathrm{MnO}_{2}: \gamma$ $\mathrm{MnO}_{2}$ (nsutite), $\alpha-\mathrm{MnO}_{2}$ (cryptomelane), $\delta-\mathrm{MnO}_{2}$ (birnessite), $\varepsilon-\mathrm{MnO}_{2}, \lambda-\mathrm{MnO}_{2}, \mathrm{R}-\mathrm{MnO}_{2}$ (ramsdellite), and $\beta-\mathrm{MnO}_{2}$ (pyrolusite). $\mathrm{MnO}_{2}$ can be divided into three categories based on various links of basic structure: tunnel structures (types $\alpha$-, $\beta$-, and $\gamma-\mathrm{MnO}_{2}$ ); sheet or layered structure $\left(\delta-\mathrm{MnO}_{2}\right)$; and 3D structures ( $\lambda$-type).

Several researchers have performed various methods to synthesize $\mathrm{MnO}_{2}$. Different synthesis methods such as hydrothermal [1], micro-emulsion, precipitation [2], reflux [3], radiolytic methods (gamma-ray irradiation) [4], solid-state [5], and sol-gel [6]can obtain or produce different crystallographic forms of $\mathrm{MnO}_{2}$. In general, the $\mathrm{MnO}_{2}$ structure can be synthesized through $\mathrm{Mn}^{2+}$ oxidation, $\mathrm{MnO}_{4}^{-}$reduction, redox reactions between $\mathrm{Mn}^{2+}$ and $\mathrm{MnO}_{4}^{-}$, or direct phase transformations from other manganese oxides [7].

The synthesis of $\mathrm{MnO}_{2}$ through $\mathrm{MnO}_{4}{ }^{-}$reduction by sol-gel, reflux, precipitation, and hydrothermal method has been carried out using acids and simple sugars. Zhang et al. succeeded in synthesizing manganese oxide $\left(\alpha-\mathrm{MnO}_{2}\right)$ using potassium permanganate $\left(\mathrm{KMnO}_{4}\right)$ and different inorganic acids $\left(\mathrm{HCl}, \mathrm{HNO}_{3}\right.$, and $\mathrm{H}_{2} \mathrm{SO}_{4}$ ) under reflux conditions [3]. The results showed that type and acid concentration of acid can control the formation mechanism of manganese oxide. The concentration of acid seems to play a crucial role in determining the phase of manganese oxide, whereas the type of acid is responsible for the particle size of as-synthesized manganese oxide.

Organic acid, like oxalic and citric acid, was used as a reducing agent for the reduction of $\mathrm{MnO}_{4}^{-}$by the 
precipitation method [8]. The as-synthesized $\delta$ $\mathrm{MnO}_{2}$ from these two different reducing agents have different crystallinity, morphology, $\mathrm{Mn}^{4+} \mathrm{Mn}^{3+}$ ratios and surface charges that affect the catalytic activities. The $\delta-\mathrm{MnO}_{2}$ samples were then tested for catalytic oxidation of methylene blue (MB) dye with $\mathrm{H}_{2} \mathrm{O}_{2}$ as an oxidant. The citric-prepared $\delta-\mathrm{MnO}_{2}$ showed higher degradation of $\mathrm{MB}$ than that of oxalic-prepared $\delta$ $\mathrm{MnO}_{2}$. Another reducing agent like simple sugars (glucose) has been applied by Awaluddin et al. to synthesize manganese oxides of $\alpha-\mathrm{MnO}_{2}$ by the sol-gel [6] and $\delta-\mathrm{MnO}_{2}$ by the solvent-free method [5], respectively. These manganese oxides also display a high catalytic performance as a heterogeneous Fenton catalyst for MB degradation.

In heterogeneous Fenton processes, a catalyst such as $\mathrm{MnO}_{2}$ serves to enhance the decomposition of hydrogen peroxide into highly reactive radicals, mainly hydroxyl radicals. These radicals with strong oxidizing power will attack, react non-selectively and decompose most organic contaminants into oxidized compounds such as carbon dioxide and water. Our previous report indicated that the birnessite-type manganese oxides synthesized from $\mathrm{MnO}_{4}^{-}$reduction using the two organic acids (citric and oxalic acid as reducing agents) showed promising heterogeneous Fenton catalyst in the degradation of palm oil mill effluent (POME) [9]. It was revealed that the catalytic performance of the $\mathrm{MnO}_{2}$ materials strongly depends on their structural properties, which is in turn precursor-dependence. In the present work, we report the birnessite-type manganese oxide synthesized by the solvent-free method using simple sugar as reducing agents. The use of simple sugar i.e. glucose as a reducing agent in the synthesis of $\mathrm{MnO}_{2}$ and its application for degradation of POME has never been reported previously.

\section{EXPERIMENTAL}

The materials and reagents used in this work included potassium permanganate (Merck), glucose (Merck), hydrochloric acid (Merck), hydrogen peroxide (Merck), mercury (II) sulfate, ammonium iron (II) sulfate hexahydrate (Merck), potassium dichromate (Merck), silver sulfate (Merck), sulphuric acid (Merck), and phenanthroline monohydrate (Merck). All the chemicals were analytical grade and used without further purification.

\subsection{Synthesis}

The manganese oxide was prepared by a solventfree method as described by our previous work [5]. The mole ratio of $\mathrm{KMnO}_{4}$ and glucose was 3:1 and calcined at $500^{\circ} \mathrm{C}$ for 7 hours.

\subsection{Characterization}

X-ray diffraction (XRD) analysis was carried out using an X-ray powder diffractometer (Rigaku) equipped with $\mathrm{CuK} \alpha$ radiation (1.54060 Å). Surface morphology was carried out by field emission scanning electron microscopy and elemental contents were evidenced by energy-dispersive X-ray (EDX) spectroscopy (JSM-6510LV). The surface area of the synthesized materials was determined by using a BELSORP-max instrument (BEL Japan) at $77 \mathrm{~K}$.

\subsection{Catalytic Activity}

The palm oil mill effluent (POME) used for this study was collected from the palm oil mill in Kampar, Riau, Indonesia. The samples were transported to the laboratory and stored in the refrigerator prior to use. The handling sample method refers to the Indonesian National Standard (6989.59:2008). The catalytic reaction was carried out in a glass flask that contained POME and an amount of as-synthesized manganese oxide as a catalyst. After adding $30 \quad$ wt $\% \quad \mathrm{H}_{2} \mathrm{O}_{2}$ solutions, the mixture was allowed to react and continuously stirred magnetically. At a given interval time, the mixture was pipetted into a volumetric flask and quickly diluted with distilled water, and ready to analyze. For COD analysis, the diluted solution was performed according to the Indonesian National Standard (6989.73:2009). The activity of the catalyst was performed three times in identical experiments.

\section{RESULT AND DISCUSSION}

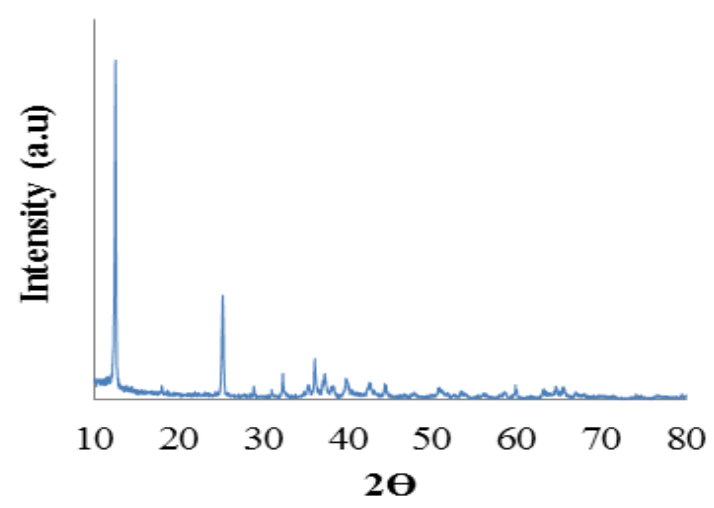

Figure 1 XRD patterns of the as-synthesized manganese oxide

The typical XRD patterns presented in figure 1 were identified as manganese oxide birnessite-type (JCPDS No. 80-1098). The main diffraction peaks at this spectrum are assigned to the (lllll $\left.\begin{array}{lll}0 & 0 & 1\end{array}\right),\left(\begin{array}{lll}0 & 0 & 2\end{array}\right),\left(\begin{array}{ll}2 & 0\end{array}\right.$ 1), (-1 11 1), ( $\left.\begin{array}{lll}2 & 0 & 1\end{array}\right)$ and $\left(\begin{array}{lll}-1 & -1 & 2\end{array}\right)$ with diffraction peak at $2 \theta$ were $12.49(7.08 \AA) ; 25.13(3.54 \AA) ; 37.23$

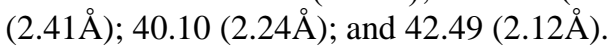




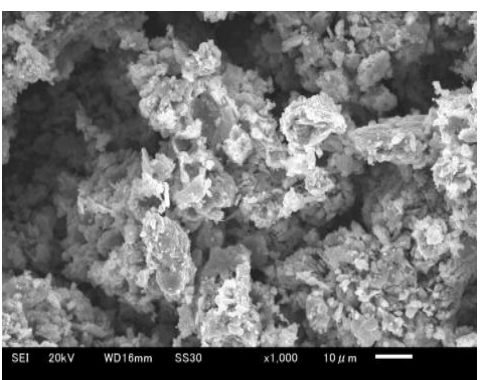

(a)

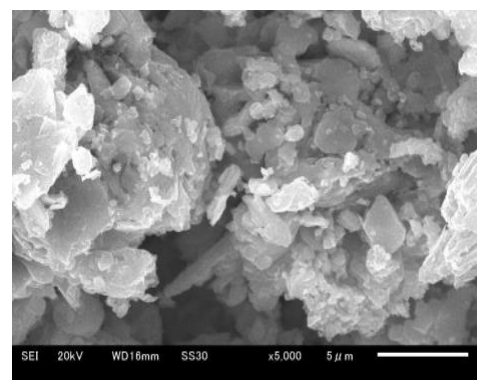

(b)

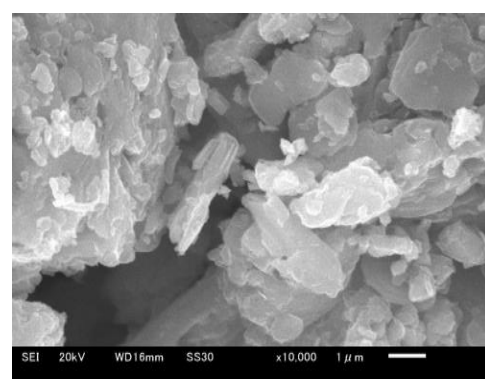

(c)

Figure 2 SEM images of the as-synthesized manganese oxide, Mag.x (a) 1000x; (b) 5000x; (c) 10000x.

Table 1. Textural properties of the as-synthesized manganese oxide

\begin{tabular}{|l|c|c|c|}
\hline Parameter & Glucose $^{\text {a) }}$ & Citric acid $\left[{ }^{9}\right]$ & Oxalic acid $\left[{ }^{9}\right]$ \\
\hline Surface area $\left(\mathrm{m}^{2} / \mathrm{g}\right)$ & 4.1802 & 5.725 & 10.544 \\
\hline Volume pore $(\mathrm{cc} / \mathrm{g})$ & 0.0216 & 0.028 & 0.054 \\
\hline Average pore radius $(\mathrm{nm})$ & 20.668 & 19.658 & 20.369 \\
\hline Pore distribution $(\mathrm{nm})$ & 78.01 & 79.010 & 167.750 \\
\hline
\end{tabular}

The surface morphology of the as-synthesized manganese oxide was investigated by SEM as shown in figure 2. From the image, it was revealed that the $\delta$ $\mathrm{MnO}_{2}$ particles obtained in this work consist of aggregate particles with more irregular sizes compared to birnessite that was calcined at $700^{\circ} \mathrm{C}$ for 7 hours [5]. This morphology with irregular sizes is also generated from using organic acid as a reducing agent via a solvent-free method [9].

The previous studies reported the production of birnessite-type manganese oxide using the same method as current work with organic acids as reducing agents. However, the synthetic condition and type of reducing agents have a significant effect on the structural properties of the manganese oxides. From Table 1, it is revealed that the surface area from the current work is $4.1802 \mathrm{~m}^{2} / \mathrm{g}$, which is lower than that of citric or oxalicprepared birnessite. The surface area obtained in this work is higher than our previous study using the same reducing agent with higher calcination temperature The calcination at $700^{\circ} \mathrm{C}$ leads to the reduction of the surface area into $3.564 \mathrm{~m}^{2} / \mathrm{g}$ and $23.1278 \mathrm{~m}^{2} / \mathrm{g}$ for the specific surface area [5]. In general, the low surface area was obtained at high calcination temperature due to sintering processes. Figure 3 showed the adsorption-desorption isothermal plot of the as-synthesized birnessite, which is similar to the isotherm type produced calcined at $700^{\circ} \mathrm{C}$ [5].

The effect of $\mathrm{H}_{2} \mathrm{O}_{2}$ concentration on the COD removal in the POME was investigated by keeping other variables (the amount of birnessite catalyst and reaction time) constant. The COD removal increases with the increase of $\mathrm{H}_{2} \mathrm{O}_{2}$ concentration as shown in figure 4 .
The optimum value of $\mathrm{H}_{2} \mathrm{O}_{2}$ concentration for the maximum COD removal is $10 \mathrm{ml}$ of $\mathrm{H}_{2} \mathrm{O}_{2}$ with $62 \%$ COD removal. It has been reported that hydrogen peroxide has a key role in the degradation process in Fenton processes as a source of hydroxyl radicals $[10,11]$. Without the addition of $\mathrm{H}_{2} \mathrm{O}_{2}$, COD removal only reached $8.13 \%$. On the other hand, figure 4 also revealed that there is a limit for COD removal with the reaction time. In this study, the high reaction time seems to decrease the COD removal. The previous studies indicated that there is a limit for the COD removal, where the percent removal of COD begins to decrease as observed by Yulia et al. (2016) [12]. According to Youssef et al. (2016) and $\mathrm{Yu}$ et al. (2014), the excess $\mathrm{H}_{2} \mathrm{O}_{2}$ can react with hydroxyl radicals, thus acting as a hydroxyl scavenger $[10,13]$.

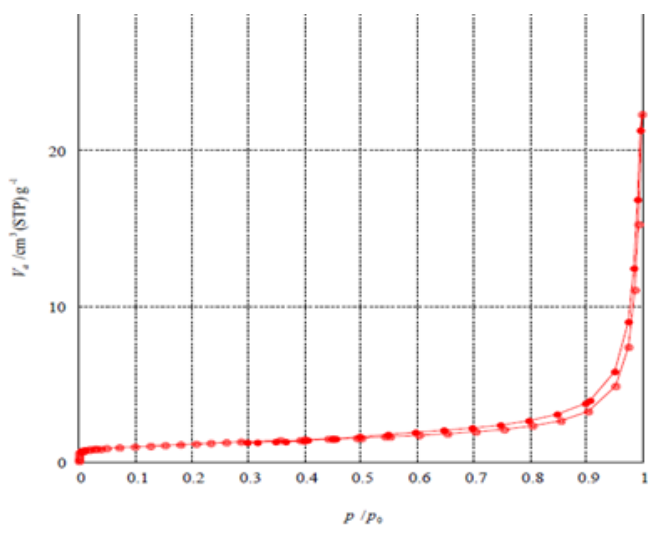

Figure 3 Profile isotherm adsorption-desorption of the as-synthesized manganese oxide 


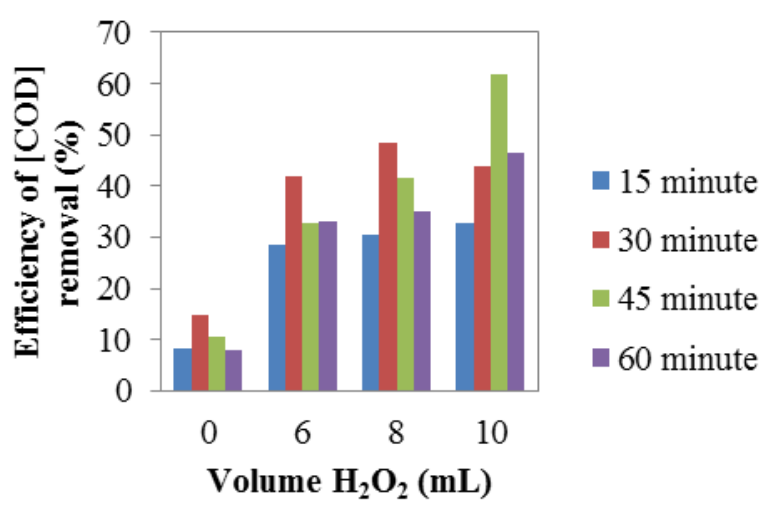

Figure 4 Effect of $\mathrm{H}_{2} \mathrm{O}_{2}$ concentration in COD removal using $400 \mathrm{mg} / \mathrm{L}$ of catalyst

Figure 5 displayed the effect of catalyst (birnessitetype manganese oxide) concentration on the COD removal of the POME. It is observed that the effect of catalyst concentration on COD removal is insignificant. The high catalyst concentration seems to have a negative effect on the COD removal. The previous study reported that the COD removal relied upon the precursor used for the synthesis of manganese oxide. The use of citric acid for the synthesis of manganese oxide produced $61 \%$ of COD removal, whereas oxalic acid precursor for the synthesis of manganese oxide resulted in $56 \%$ of COD removal, respectively [9]. It is evident that the different textural properties (table 1) of the manganese oxides used as Fenton catalyst play a key role in the COD removal of the POME. From this study, the as-synthesized birnessite-type manganese oxide is promising as a Fenton catalyst for the reduction of COD values, although further research is still needed to obtain the best conditions for degradation of POME using $\mathrm{H}_{2} \mathrm{O}_{2}$ and birnessite-type manganese oxide as a catalyst.

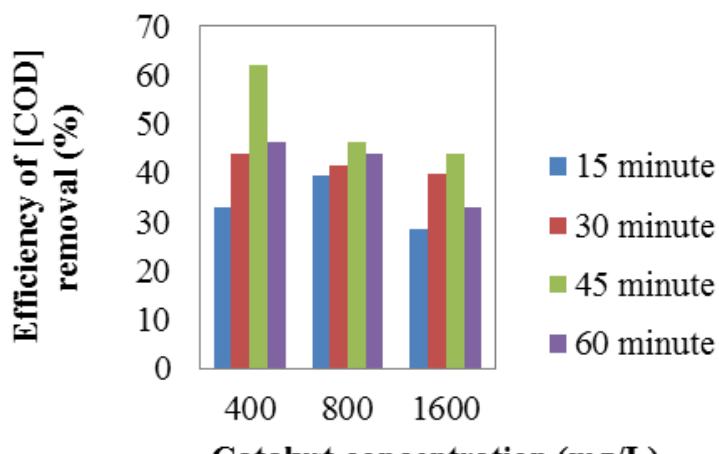

Catalyst concentration (mg/L)

Figure 5 Effect of catalyst concentration in COD removal using $10 \mathrm{ml}$ of $\mathrm{H}_{2} \mathrm{O}_{2}$

\section{CONCLUSION}

The birnessite-type manganese oxide has been successfully synthesized from the reduction of $\mathrm{MnO}_{4}^{-}$ by simple sugar (glucose) as a reducing agent using a solvent-free method and was applied as a heterogeneous Fenton catalyst for the degradation of Palm Oil Mill Effluent (POME). The maximum COD removal was $62 \%$ obtained in reaction conditions of $10 \mathrm{ml}$ of $\mathrm{H}_{2} \mathrm{O}_{2}$ concentration and catalyst concentration of $400 \mathrm{mg} / \mathrm{L}$. $\mathrm{H}_{2} \mathrm{O}_{2}$ concentration seems to play an important role in COD removal.

\section{ACKNOWLEDGMENTS}

This work was supported by the Ministry of Research and Technology of the Republic of Indonesia through the PDUPT research grant on behalf of Prof. Dr. Amir Awaluddin, M.Sc.

\section{REFERENCES}

[1] X. Zheng, T. Lin, G. Cheng, B. Lan, M. Sun, L. $\mathrm{Yu}$, Hollow bipyramid $\beta-\mathrm{MnO}_{2}$ : Pore size controllable synthesis and degradation activities, Advanced Powder Technology, vol 26, 2015, pp. 622-625.

DOI: https://doi.org/10.1016/j.apt.2015.01.012

[2] A. Awaluddin, R. Zulfa, S. Absus, Nurhayati, A. Linggawati, S.S. Siregar, The enhanced catalytic activities of octahedral layer birnessite-type manganese oxide synthesized via precipitation method for the degradation of methylene blue, in: IOP Conference Series: Materials Science and Engineering, vol 509, IOP Publishing, 2019, 012011. DOI: https://doi.org/10.1088/1757899X/509/1/012011

[3] Q. Zhang, X, Cheng, G, Qiu, F, Liu, X, Feng, Sizecontrolled synthesis and formation mechanism of manganese oxide OMS-2 nanowires under reflux conditions with $\mathrm{KMnO}_{4}$ and inorganic acids, Solid State Sciences, 2016, vol. 55, pp. 152-158. DOI: https://doi.org/10.1016/j.solidstatesciences.2016.03 .003

[4] F.W. Boyom-Tatchemo, F. Devred, G. NdiffoYemeli, S. Laminsi, E.M. Gaigneaux, Plasmainduced redox reactions synthesis of nanosized $\alpha$-, $\gamma$ - and $\delta-\mathrm{MnO}_{2}$ catalysts for dye degradation, Applied Catalysis B: Environmental, vol. 260, 2020, pp. 118159. DOI:https://doi.org/10.1016/j.apcatb.2019.118159

[5] S.S. Siregar, A. Awaluddin, Synthesis and catalytic activity of Birnessite-Type Manganese Oxide synthesized by solvent-free method, in: IOP Conference Series: Materials Science and Engineering, vol 345, IOP Publishing, 2018, pp. 012005. DOI:10.1088/1757-899X/345/1/012005

[6] A. Awaluddin, M. Agustina, R.R. Aulia, Muhdarina, Precursor effects on the morphology 
and crystallinity of manganese oxides and their catalytic application for methylene blue degradation, in: AIP Conference Proceedings, vol 1823, IOP Publishing, 2017, 020108. DOI: https://doi.org/10.1063/1.4978181

[7] X. Liu, C. Chen, Y. Zhao, B. Jia, A Review on the Synthesis of Manganese Oxide Nanomaterials and Their Applications on Lithium-Ion Batteries, Journal of Nanomaterials, vol. 2013, 2013, pp. 1-7. DOI: http://dx.doi.org/10.1155/2013/736375

[8] R. Zulfa, S, Absus, A. Awaluddin, S. Anita, S.S. Siregar, Zulfikri, Effect of Precursors on Morphology and Catalytic Activities of Birnessite for Methylene Blue Degradation Effect of Precursors on Morphology and Catalytic Activities of Birnessite for Methylene Blue Degradation, in: IOP Conference Series: Journal of Physics, vol. 1097, IOP Publishing, 2018, 012051. DOI: https://doi.org/10.1088/1742-6596/1097/1/012051

[9] A. Awaluddin, Muhdarina, W. Chaerani, M.A. Pratiwi, S.S. Siregar, Synthesis of birnessite-type manganese oxide from two different reducing agents via solvent-free method and the catalytic activity in degradation of POME, in IOP Conference Series: Journal of Physics, vol. 1397, IOP Publishing, 2019, 012028. DOI: https://doi.org/10.1088/1742-6596/1397/1/012028
[10 C. Yu, G. Li, L. Wei, Q. Fan, Q. Shu, J.C. Yu, Fabrication, characterization of $\beta-\mathrm{MnO}_{2}$ microrod catalysts and their performance in rapid degradation of dyes of high concentration, Catalysis Today, vol. 224, 2014, pp. 154-162. DOI: https://doi.org/10.1016/j.cattod.2013.11.029

[11] L, Zhang, Y. Nie, C, Hu, X, Hu, Decolorization of methylene blue in layered manganese oxide suspension with $\mathrm{H}_{2} \mathrm{O}_{2}$, Journal of Hazardous Materials, vol. 190, 2011, pp. 780-785. DOI: https://doi.org/10.1016/j.jhazmat.2011.03.120

[12] R. Yulia, H. Meilina, Adisalamun, Darmadi, Aplikasi Metode Advance Oxidation Process (AOP) Fenton pada Pengolahan Limbah Cair Pabrik Kelapa Sawit Application of Advanced Oxidation Process (AOP) Fenton on Palm Oil Mill Effluent Treatment, Jurnal Rekayasa Kimia dan Lingkungan, vol. 11(1), 2016, pp. 1-9. DOI: https://doi.org/10.23955/rkl.v11i1.4098

[13] N.A. Youssef, S.A. Shaban, F.A. Ibrahim, A.S. Mahmoud, Degradation of methyl orange using Fenton catalytic reaction. Egyptian Journal of Petroleum, 2016, vol. 25(3), pp. 317-321. DOI: https://doi.org/10.1016/j.ejpe.2015.07.017 